\title{
JAKÝ JE IDEÁLNÍ MODEL ODPOVĚDNOSTI ZA AUTONOMNÍ SYSTÉM?
}

\author{
JAN TOMÍŠEK ${ }^{1}$
}

\begin{abstract}
ABSTRAKT
Př́spěvek se věnuje praktickým otázkám odpovědnosti za škody způsobené autonomními systémy, $u$ nichž je obtižná předvídatelnost a prevence škod a rovněž obtížné určení príčiny vzniku konkrétní škody s ohledem na konstrukci systémů a množství datových vstupů. Na základě analýzy ideálního modelu odpovědnosti za takové systémy je diskutována stávající úprava odpovědnosti za provoz zvláště nebezpečný a odpovědnosti za vady výrobku dle občanského zákoníku. Odpovědnost za provoz zvláště nebezpečný je vyhodnocena jako vhodný model odpovědnosti provozovatele systému a je navrhováno jeji doplnění systémem povinného pojištění. Ve vztahu k odpovědnosti za vady výrobku je pak navrhováno rozšírení liberačních podmínek a rozšǐření odpovědnosti na vady softwarových autonomních systémů.
\end{abstract}

\section{KLÍČOVÁ SLOVA}

umělá inteligence; odpovědnost; autonomní systém

\begin{abstract}
This paper deals with practical issues of liability for damages caused by autonomous systems where it is (considering design of the relevant systems and the vo-

\footnotetext{
Autor je externím doktorandem na Ústavu práva a technologií Právnické fakulty MU a advokátem v advokátní kanceláři ROWAN LEGAL. Článek nevyjadřuje názory žádné ze jmenovaných institucí. Autor děkuje anonymnímu recenzentovi za podnětné připomínky k tomuto textu. Vznik článku byl podpořen z projektu specifického výzkumu Masarykovy univerzity MUNI/A/1015/2017. Kontaktní e-mail: tomisek@rowanlegal.com
} 
lume of data inputs) difficult to predict and prevent a damage and also difficult to determine the cause of the specific damage. Based on an analysis of the ideal liability model for such systems, current rules laid down in Czech Civil Code regarding liability for dangerous facility and product liability are discussed. Regime of liability for dangerous facility is found suitable as a liability model for autonomous system and it is proposed to be supplemented by a compulsory insurance system. With regard to product liability, it is proposed to broaden conditions for liability liberation and extend accountability to the defects of purely software autonomous systems.

\section{KEYWORDS}

artificial intelligence; liability; autonomous system

\section{1. ÚVOD}

Autonomní systémy a umělá inteligence čím dál častěji poutají pozornost právníků. Důkazem je řada publikací $\mathrm{v}$ českých právnických periodicích $\mathrm{k}$ tomuto tématu $\mathrm{z}$ poslední doby. ${ }^{2}$ Rozpětí možných př́stupů $\mathrm{k}$ tématu je přitom široké. Na jednu stranu se můžeme setkat s diskuzemi o umělé inteligenci jako třetím typu osoby s nutností vlastní právní subjektivity, a to zejména $\mathrm{v}$ kontextu možného rozvoje vlastního vědomí $\mathrm{v}$ autonomních systémech, ${ }^{3}$ což lze spíše považovat za problém vzdálené budoucnosti.

Na druhé straně spektra stojí ryze praktické diskuze o modelech odpovědnosti za autonomní systémy, s jakými se dnes můžeme běžně setkat, nebo se s nimi budeme moci setkat v nejbližší budoucnosti, jako jsou např. autonomní vozidla či softwarové systémy nahrazující člověka při komuni-

\footnotetext{
Srov. např̀. POLČÁK, R. Odpovědnost umělé inteligence a informační útvary bez právní osobnosti. In: V. ZOUFALÝ. XXVI. Karlovarské právnické dny. Praha: Leges, 2018. s. 535554. Dále srov. KRAUSOVÁ, A. Status elektronické osoby v evropském právu v kontextu českého práva. Právní rozhledy, 2017, č. 20, s. 700 a násl. KOLAŘíKOVÁ, L. Odpovědnost (za) robota aneb právo umělé inteligence. Bulletin advokacie. 2018, č. 3. s. 11-19. MIKEŠ, S. Právo ve věku inteligentních strojủ. Bulletin advokacie. 2018, č. 4. s. 17-22. MIKEŠ, S. Vybrané otázky odpovědnosti za škodu způsobenou autonomním vozidlem. Právní rozhledy. [online] 2018, č. 13-14. [cit. 14. 8. 2018]. Citováno dle beck-online.cz

3 Srov. MIKEŠ, Bulletin advokacie, 2018, op. cit. s. 18.
} 
kačních úlohách. ${ }^{4}$ K širokému rozpětí svých stanovisek směřují i právotvorné orgány. ${ }^{5}$

Tento prríspěvek má ambici se zařadit ke druhé citované skupině a pragmaticky analyzovat, jak by měl vypadat model soukromoprávní odpovědnosti za újmu způsobenou autonomním systémem, který není nadán schopností vlastního sebeuvědomění, ale je schopen pracovat bez zásahu člověka bud' pod jeho dohledem, nebo bez tohoto dohledu.

Příkladem takového systému je autonomní vozidlo, na němž jsou ilustrovány typické vlastnosti takového systému. Předmětem tohoto př́spěvku však není řešení speciální právní úpravy provozu dopravních prostředků, ale diskuze obecného modelu soukromoprávní odpovědnosti. Zohledněny jsou proto rovněž ryze softwarové systémy bez hmotné složky. Předmětem diskuze v rámci příspěvku naopak není odpovědnost veřejnoprávní (zejména správněprávní a trestní). ${ }^{6}$

Část 2 př́spěvku tvoří analýza pojmu autonomní systém a identifikace jeho vlastností, které mají dopad do odpovědnostního modelu. V části 3 jsou pak na základě těchto vlastností identifikovány požadavky na ideální odpovědnostní model. $\mathrm{V}$ rámci části 4 jsou diskutovány jednotlivé relevantní odpovědnostní instituty dle zákona č. 89/2012 Sb., občanský zákoník, ve znění pozdějších předpisů (dále jen „ObčZ“), aplikovatelné na újmu způsobenou autonomním systémem. Zejména je diskutována odpovědnost za provoz zvláště nebezpečný a odpovědnost za vady výrobku. Na základě této diskuze jsou v části 5 činěny návrhy de lege ferenda.

V závěru příspěvku autor shrnuje, že pro spravedlivou kompenzaci osob, jimž autonomní systém způsobí újmu, je třeba odpovědnost za takovou

4 Srov. POLČÁK, 2018, op. cit. MIKEŠ, Právní rozhledy, 2018.

5 Srov. usnesení Evropského parlamentu ze dne 16. února 2017 obsahující doporučení Komisi o občanskoprávních pravidlech pro robotiku (2015/2103(INL)), zejména body Z až AI a 49 až 57 řešících primárně odpovědnosti, oproti bodu 58 navrhujícímu status elektronické osoby.

6 K tomu srov. např. SOKOL, T.; SMEJKAL, V. Trestněprávní aspekty robotiky - část I. Právní prostor [online]. 6. $9.2018 \quad$ [cit. $15 . \quad 12 . \quad 1018$ ]. Dostupné z: https://www.pravniprostor.cz/clanky/trestni-pravo/trestnepravni-aspekty-robotiky a SOKOL, T.; SMEJKAL, V. Trestněprávní aspekty robotiky - část II. Právní prostor [online]. 2. 10. 2018 [cit. 15. 12. 1018]. Dostupné z: https://www.pravniprostor.cz/clanky/trestnipravo/trestnepravni-aspekty-robotiky-cast-ii 
újmu modelovat jako objektivní, alokovanou na provozovatele autonomního systému, čemuž odpovídá úprava odpovědnosti za provoz zvláště nebezpečný dle ObčZ. Odpovědnost za vady výrobku by ve vztahu k autonomním systému měla být rozšířena na software, ale limitována na případy, kdy původce př́slušného autonomního systému neprovede opatření, která mohl rozumně učinit pro prevenci újmy. Tento model odpovědnosti by dle názoru autora měl být doplněn systémem povinného pojištění a krytí nepojištěných škod, obdobně jako u motorových vozidel.

\section{AUTONOMNÍ SYSTÉM}

Typickým příkladem autonomního systému relevantního pro tento př́spěvek je autonomní vozidlo. Očekáváme, že takové vozidlo bude samostatně vykonávat určité svěřené úkoly, např. přepravovat osoby a věci z místa na místo, doplňovat palivo, resp. zásoby energie apod. V současnosti takové úkoly může vykonávat pod dohledem člověka, $\mathrm{v}$ blízké budoucnosti pak bez jeho dohledu. Neočekáváme však, že by v nejbližší budoucnosti autonomní vozidlo mělo vlastní inciativu, uvědomovalo si sebe sama a mohlo si úkoly stanovovat samo. Jeho chování tak bude vždy funkcí výchozího vloženého softwaru a získaných dat.

Prvním významným znakem autonomního systému je proto jeho nízká kontrolovatelnost a obtížné zabránění nepředvídanému nežádoucímu chování. Pokud určitý systém pracuje skutečně autonomně, jeho vlastník či provozovatel (zjednodušeně řečeno ten, kdo ho „vypustil do světa“), zpravidla nemůže kontrolovat, jakým datovým vstupům bude vystaven. Např́klad majitel autonomního vozidla nemůže ovlivnit, jaká bude podoba a obsah dopravního značení, se kterým se vozidlo setká. ${ }^{7}$ Tyto datové vstupy přitom nemusí ovlivnit jen aktuální chování autonomního systému (např. vozidlo může způsobit dopravní nehodu na základě chybného či úmyslně upraveného dopravního značení), ale také jeho chování v budoucnu.

\footnotetext{
7 Takové dopravní značení je přitom možné použít $\mathrm{k}$ útoku působícímu nežádoucímu chování autonomního vozidla. Srov. EVTIMOV, Ivan, a kol. Robust Physical-World Attacks on Deep Learning Models. arXiv.org [online]. Upraveno 10. 4. 2018 [cit. 14. 8. 2018].
} 
Pro chování vozidla však budou významná nejen data získávaná vozidlem během jednotlivé jízdy (např. o chování dalších vozidel a stavu vnějšího prostředí), ale také data získaná v minulosti a zpracovaná metodou tzv. strojového učení. ${ }^{8}$ Pomocí strojového učení je chování autonomního systému modelováno veškerými předchozími daty zpracovanými tímto systémem (resp. jejich relevantní podmnožinou).

Příkladem může být strojové učení vozidla v zemi, kde chodci striktně respektují světla na semaforu. Na základě strojového učení za takto specifických podmínek může vozidlo způsobit dopravní nehodu v jiné zemi, kde chodci červené světlo na semaforu vnímají spíše jako doporučení se na přechodu lépe rozhlédnout. Vozidlo totiž nebude předpokládat, že by chodec po dobu, kdy svítí červené světlo, mohl vstoupit do vozovky, a proto nepojede s náležitou opatrností. Chování samotných chodců během procesu strojového učení je přitom opět mimo kontrolu vlastníka, resp. provozovatele. $^{9}$

Druhým významným znakem autonomního systému je obtížnost určení příčiny jeho nežádoucího chování, a to díky množství datových vstupů a strojovému učení. Pokud např. autonomní vozidlo prudce zabrzdí a způsobí srážku s vozidlem za ním, může být obtížné určit, zda příčinou prudkého brždění byl některý z mnohých aktuálních datových vstupů (např. konkrétní zmanipulovaná dopravní značka či varování, že jiné autonomní vozidlo se blíží zpoza rohu), nastavení vozidla výrobcem, nastavení jeho obsluhou, nebo nastavení vzniklé strojovým učením.

Díky strojovému učení autonomní systém současně neustále koriguje svůj způsob reakce na určité vstupy, tyto korekce se však neukládají formou pravidla či algoritmu srozumitelného pro člověka, ale např. posi-

Blí̌ze srov. např. ALPAYDIN, E. Introduction to machine learning. Cambridge, Massachusetts: The MIT Press. 2014.

9 Radim Polčák v tomto směru uvádí př́ílad autonomního systému společnosti Microsoft nazvaného Tay, jehož úlohou bylo vytvářet příspěvky na sociální sít Twitter, které bude sdílet co nejvíce uživatelů. Při několika pokusech o jeho nasazení však došlo $\mathrm{k}$ tomu, že v reakci na dostupný obsah na dané sociální síti a také cílené jednání některých jejich dalších uživatelů začal systém vytvářet nenávistné př́spěvky, aniž by $\mathrm{k}$ tomu společnost Microsoft jakkoli zavdala. Srov. POLČÁK, 2018, op. cit., s. 538. Obecně k problému omezené kontroly nad autonomním systémem pak srov. tamtéž s. 539 a násl. 
lováním nebo oslabováním určitých vazeb v neuronové síti. Následně proto nemusí být zřejmé, proč na určité vstupy reagoval systém určitým způsobem, a které minulé datové vstupy vedly $\mathrm{k}$ vytvoření konkrétního reakčního modelu.

V kontextu výše uvedeného př́kladu nemusí být například zřejmé, jak se autonomní vozidlo naučilo předpokládat, že na červenou chodci zásadně nevstupují do vozovky - zda přičinou byl nevhodný „trénink“ jeho výrobcem, resp. dodavatelem, ${ }^{10}$ používání $\mathrm{v}$ atypickém provozu nebo prostě běžné chování lidí v určité oblasti, kde bylo vozidlo legitimně provozováno. ${ }^{11}$

Autonomní vozidlo tak dobře ilustruje typické znaky autonomního systému, relevantní pro analýzu a diskuzi vhodného odpovědnostního modelu, tj. nízkou kontrolovatelnost a obtížnost určení př́činy nežádoucího chování. Předmětem diskuze $\mathrm{v}$ tomto příspěvku však není odpovědnost za autonomní vozidla jako taková, nebot ta zpravidla podléhají specifické regulaci. ${ }^{12}$ Pro korektní analýzu a diskuzi je třeba pojem autonomní systém vnímat $\mathrm{v}$ jeho plné šiři, která zahrnuje též systémy bez hmotné složky, tj. systémy ryze softwarové. Typickým př́kladem zde může být autonomní systém suplující roli burzovního makléře.

Bylo by přitom chybou se domnívat, že softwarový systém je méně nebezpečný než systém, který svou hmotnou složkou může způsobit hmotou újmu. Př́klad autonomního systému realizujícího transakce na burze zde není tolik ilustrativní, pokud si však představíme autonomní systém zajištující řízení jaderné elektrárny, mimo jiné např. na základě dat z energetické distribuční soustavy, je srozumitelnější, že případná újma je s újmou způsobenou systémem $\mathrm{s}$ hmotnou složkou přinejmenším srovnatelná.

10 Je běžné, že autonomní systém je před zahájením svého obvyklého provozu nejprve „trénován" na cvičných datových vstupech, aby se na nich naučil odpovídající reakce a podle nich byl schopen reagovat adekvátně na obdobné vstupy.

${ }^{11}$ K obdobnému argumentu o obtižné analýze příčin určitého jednání srov. POLČÁK, 2018, op. cit., s. 539.

12 Srov. např. VÁCHAL, A. Česko dohání Německo a Kalifornii v autonomním řízení. Do sněmovny mírí novela, která povolí samořiditelná auta. IHNED.cz [online]. 14. 6. 2018 [cit. 14. 8. 2018]. K bližší diskuzi odpovědnosti za autonomní vozidla srov. MIKEŠ, 2018, č. 1314, op. cit. 
S ohledem na to, že autonomní systém může být systémem ryze softwarovým a u softwarového systému lze jen stěží hovořit o výrobě a výrobci, jsou v dalším výkladu výrobce autonomního systému s hmotnou složkou a tvůrce softwarového systému označováni souhrnně jako původce autonomního systému.

\section{POŽADAVKY NA MODEL ODPOVĚDNOSTI}

\subsection{PREVENTIVNÍ PŮSOBENÍ}

Při hledání vhodného modelu odpovědnosti za autonomní systém je třeba mít na paměti skutečnost, že nastavení odpovědnosti za újmu má významný vliv na chování subjektů příslušných odpovědnostních vztahů. Tento vliv může být pozitivní a vést $\mathrm{k}$ bezpečnějším a kvalitnějším autonomním systémům a minimalizaci celkové újmy vzniklé společnosti působením autonomních systémů. Současně však může být i negativní, pokud odradí subjekty odpovědnostních vztahů od jinak společensky přínosných aktivit, které jsou spojeny s př́liš vysokým rizikem vzniku povinnosti k náhradě újmy (např. pokud budou vývoj či distribuce jinak prospěšného autonomního systému spojeny s rizikem náhrady újmy a toto riziko nepůjde krýt pojištěním odpovědnosti za škodu). ${ }^{13}$

Pozitivní působení směrem $\mathrm{k}$ bezpečnějším a kvalitnějším produktům a službám vzniká tam, kde je původce daného autonomního systému za něj činěn odpovědným. $Z$ ekonomického hlediska se racionálně chovající původce bude snažit maximalizovat svůj zisk ze šíření daného autonomního systému, přičemž případná náhrada újmy tento zisk snižuje. Proto bude původce vynakládat úsilí a prostředky, aby pravděpodobnost nastoupení povinnosti k náhradě újmy snížil, a to až do okamžiku, kdy dodatečné preventivní opatření má náklady vyšší, než o kolik by se snížila možná nahrazovaná újma vážená její pravděpodobností. ${ }^{14}$

$\mathrm{V}$ tomto kontextu je však třeba si uvědomit, že pokud by odpovědnost původce byla absolutní a žádná opatření nebyla dostatečná k tomu, aby se

${ }^{13}$ Srov. HUBBARD, 2014, op. cit., s. 1833.

14 Srov. HUBBARD, 2014, op. cit., s. 1812 a násl. 
jí původce zprostil, pak by tato ekonomická motivace $\mathrm{k}$ investicím do preventivních opatření vůbec nenastoupila. To nelze považovat za žádoucí výsledek.

Pokud by naopak odpovědnost původce autonomního systému byla $\mathrm{v}$ určitém případě omezena či dokonce vyloučena, mělo by takové nastavení stimulující účinek ve vztahu $\mathrm{k}$ vývoji a šíření nových autonomních systémů, protože jeho původce by nebyl zatížen rizikem odpovědnosti a s ním souvisejícími náklady. Na druhou stranu by se stejně jako v př́ípadě absolutní odpovědnosti snížila či zcela vytratila motivace původce $\mathrm{k}$ vynakládaní prostředků na rozumná opatření bránící vzniku újmy. ${ }^{15}$

V kontextu výše uvedené analýzy by proto ideální model odpovědnosti měl alokovat odpovědnost za škodu vzniklou autonomním systém na jeho původce do té míry, aby byl motivován činit preventivní opatření proti vzniku škod do té míry, kdy je ekonomičtější prevence než řešení vzniklých škod. Odpovědnost původce autonomního systému by neměla být absolutní a nezávislá na investicích do prevence, neměla by však být současně vyloučena.

\subsection{ROZLOŽENÍ ODPOVĚDNOSTI MEZI PŮVODCE A PROVOZOVATELE} Významnou otázkou je, zda má být př́ípadná odpovědnost alokována původci či provozovateli autonomního systému, pokud takový systém způsobí újmu. Původce autonomního systému má nejlepší znalost o jeho fungování a situacích či podmínkách, ve kterých může autonomní systém újmu způsobit. Na druhou stranu nemusí mít původce autonomního systému podrobnou znalost o tom, jakým způsobem může být daný autonomní systém jeho provozovatelem použit a jaká újma s daným způsobem použití může být spojena.

Jak uvádí Polčák, na straně původce bude potenciální odpovědnost v praxi nejčastěji řešena pojištěním odpovědnosti za škodu, ${ }^{16}$ přičemž výše pojistného se bude odvíjet od předpokládané výše možné újmy a promítat do pořizovací ceny autonomního systému. S ohledem na omezenou znalost

\footnotetext{
15 Srov. HUBBARD, 2014, op. cit., s. 1869 a násl.

16 Srov. POLČÁK, 2018, op. cit., s. 542.
} 
možného způsobu využití může být stanovení této předpokládané výše újmy obtížné a původce systému bude muset počítat s nejhorším scénářem. Výsledkem může být výrazné navýšení pořizovací ceny autonomního systému kvůli výši pojistného, ačkoli náklady na pojištění by na straně provozovatele mohly být se znalostí konkrétního způsobu použití výrazně nižší. Takové navýšení pak může limitovat využití jinak prospěšných a finančně dostupných autonomních systémů.

Zohlednit je proto třeba konkrétní postavení původce a provozovatele autonomního systému. $\mathrm{V}$ př́padě softwarového autonomního systému, jehož původcem bude nezávislý vývojář či menší společnost, ale provozovatelem renomovaná finanční instituce, je z hlediska kompenzace poškozeného pravděpodobně vhodnější odpovědnost provozovatele. Naopak v případě autonomního hlasem ovládaného domácího asistenta, jehož původcem je významný výrobce spotřební elektroniky a který je určen primárně pro využití spotřebiteli, je naopak vhodnější, aby poškozený měl možnost hojit se prímo na původci systému.

V prvém případě navíc může být původce tvůrcem relativně obecného systému určeného obecně pro komunikaci se zákazníky a automatizaci zákaznických procesů a může to být konkrétní finanční instituce, která rozhodne, že daný systém použije např. pro poradenství klientům o vhodných investičních produktech. Takový způsob použití může při špatné radě vést k významné újmě na straně klienta finanční instituce, aniž by taková újma na straně původce obecného systému byla předvídatelná. Naopak v druhém př́padě bude pro př́islušného výrobce spotřební elektroniky relativně dobře předvídatelné, jakým způsobem budou spotřebitelé přrislušný systém používat, a tedy pro něj bude předvídatelná i hrozící újma.

Je tedy patrné, že původce autonomního systému by neměl být z odpovědnosti zcela vyňat, protože je v dobrém postavení, aby možné škodě předešel, a v některých případech též aby posoudil odpovídající rizika a adekvátně se proti nim pojistil. Těžiště odpovědnosti by však dle názoru autora mělo ležet na provozovateli systému, který je nejlépe schopen posoudit rizikovost daného způsobu použití a podle něj náležitě vybrat vhodný auto- 
nomní systém s odpovídajícím bezpečnostním profilem, nebo dokonce rozhodnout, že v daném případě není vůbec vhodné autonomní systém použít.

Teprve jako druhotné opatření by měla nastupovat odpovědnost původce autonomního systému pro prrípad, že $\mathrm{v}$ daném případě nebude pro poškozeného efektivní hojit se na provozovateli systému, popř. újma poškozenému vznikla jednoznačně nedostatečnou prevencí na straně původce. Taková práva by poškozený měl mít možnost proti původci uplatňovat př́imo. $\mathrm{V}$ př́padech, kdy provozovatel systému nahradí poškozenému škodu, které mohl původce systému rozumně předejít, by současně provozovatel měl mít regres proti původci.

\subsection{KOMPENZACE POŠKOZENÝCH}

Vedle preventivního motivačního působení odpovědnostního systému nelze odhlížet od jeho významného cíle, a to je adekvátní kompenzace poškozených. ${ }^{17}$ Vznikne-li poškozenému újma vlivem činnosti autonomního systému, neměla by nastat situace, kdy poškozený za tuto újmu nebude kompenzován, vyjma rozsahu, v jakém se na vzniku újmy sám poškozený podílel.

Výše popsané vlastnosti autonomního systému, kdy je obtížné vzniku újmy předejít a současně určit její př́činu, vedou $\mathrm{k}$ závěru, že subjektivní model odpovědnosti nemůže být $\mathrm{v}$ tomto směru dostatečný. Poškozený by totiž v řadě případů nebyl schopen prokázat zavinění žádného subjektu, který by jej mohl potenciálně kompenzovat. Model odpovědnosti za autonomní systém by tedy měl být postaven na objektivním principu.

Jelikož okruh možných příčin vzniku újmy způsobené autonomním systémem je široký, bude-li jeden subjekt odpovědnostních vztahů učiněn objektivně odpovědným, nastanou v praxi případy, kdy tento odpovědný subjekt nebude tím, kdo ve skutečnosti škodu způsobil. $\mathrm{V}$ takovém př́padě by měl mít odpovědný subjekt možnost se dále hojit v rámci regresních vztahů.

Současně je třeba odpovědností model nastavit tak, aby odpovědný subjekt byl skutečně schopen poškozené adekvátně kompenzovat. V tomto

${ }_{17}$ Srov. HUBBARD, 2014, op. cit., s. 1811. 
směru je tedy nutné objektivní odpovědnost alokovat vždy na dostatečně ekonomicky silný subjekt (např. s ohledem na jeho předpokládaný ekonomický prospěch z šíření či použití autonomního systému), nebo objektivní odpovědnost doplnit jiným institutem garantujícím kompenzaci, např. povinným pojištěním odpovědnosti.

Různorodost ekonomického postavení subjektů odpovědnostních vztahů v oblasti autonomních systémů již byla diskutována v části 3.2 tohoto př́ispěvku. $\mathrm{V}$ tomto kontextu se jeví jako vhodné umožnit poškozenému hojit se na ekonomicky silném subjektu $\mathrm{v}$ daném konkrétním případě vzniku újmy (např. na původci autonomního systému, neprovedl-li adekvátní preventivní opatření proti vzniku újmy) a současně systém doplnit povinným pojištěním pro ostatní případy.

\subsection{PRÁVNÍ JISTOTA}

Motivačním faktorem pro subjekty odpovědnostech vztahů není jen samotná alokace odpovědnosti, ale také míra právní jistoty ohledně této alokace. Rozhodování původce, zda bude autonomní systém šíriit, resp. provozovatele, zda jej uvede do provozu, bude ovlivněno nejen tím, že za určitou újmu budou s jistotou odpovídat, ale také potenciální odpovědností, která je nejistá. I taková odpovědnost musí být racionálním subjektem při ekonomické kalkulaci zohledněna.

Stejně tak se tato potenciální odpovědnost promítne do kalkulace pojistného pro pojištění odpovědnosti, popř. může dokonce vést $\mathrm{k}$ tomu, že určitá činnost bude z hlediska rizik nepojistitelná. Tato skutečnost pak ovlivní pořizovací cenu autonomního systému, příp. může zpơsobit, že daný autonomní systém vůbec nebude jeho původcem šířen. ${ }^{18}$

Ideální model odpovědnosti za autonomní systém by proto subjektům odpovědnostních vztahů měl poskytovat dostatečnou právní jistotu o tom, který subjekt a za jakých okolností bude za újmu způsobenou autonomním systémem činěn odpovědným. $\mathrm{V}$ důsledku takového nastavení budou moci subjekty odpovědnostních vztahů nastavit adekvátní preventivní opatření,

18 Srov. POLČÁK, 2018, op. cit., s. 542. 
popř. si zajistit odpovídající pojištění, které bude dostupnější a méně nákladné než ve stavu právní nejistoty.

\subsection{POUŽITÍ OPEN SOURCE KOMPONENT}

Při hledání ideálního odpovědnostního modelu je třeba také brát v potaz, že autonomní systémy jsou dnes často budovány s využitím existujících komponent třetích stran. Některé (jinak vysoce komplexní) úlohy se při vývoji zejména softwarové části autonomních systémů do značné míry opakují, proto je efektivní pro ně použít již dostupná řešení. Příkladem mohou být knihovny funkcí pro strojové učení. Tyto komponenty mohou být pořízeny v rámci běžných dodavatelsko-odběratelských vztahů, ale často jsou využívána také bezplatně dostupná řešení v podobě open source softwaru. ${ }^{19}$ Újma způsobená autonomním systémem přitom může vzniknout právě selháním takové komponenty třetí strany.

Odpovědnostní model by měl tedy umožňovat v odůvodněných případech přenesení odpovědnosti původce autonomního systému na původce komponenty, jež svým selháním újmu zapř́ičinila. $\mathrm{V}$ případě běžných dodavatelsko-odběratelských vztahů by mělo jít o běžné regresní přenesení odpovědnosti, přičemž odpovědnost pưvodce komponenty by měla být konstruována obdobně jako odpovědnost původce celého systému, tj. se zohledněním, zda byla na straně původce komponenty učiněna dostatečná preventivní opatření.

Uplatnění tohoto standardu v případě open source komponent by však bylo nepřiměřené. Jakkoli vývoj open source softwaru může být komerční aktivitou, případný komerční benefit tvůrce takového softwaru se realizuje např. $\mathrm{v}$ rámci poskytování podpory $\mathrm{k}$ danému softwaru, poskytování dodatečných záruk na základě zvláštních smluvních ujednání apod. Samotný open source software je za běžných podmínek bezplatně dostupný potenciálně neomezenému okruhu osob. Pokud tedy původce autonomního systému použije pro jeho tvorbu open source software, může tak učinit bez vě-

\footnotetext{
19 Srov. SCHERER, 2016, op. cit., s. 370 a násl.
} 
domí a bez finanční kompenzace tvưrce tohoto softwaru, postačí pouze, že dodrží příslušné licenční podmínky. ${ }^{20}$

Open source software současně velmi často nemá jednoho konkrétního tvůrce, ale je vytvářen komunitou, z níž každý člen může do tvorby daného softwaru přispět relativně malým dílem, ale kombinací těchto příspěvků může vzniknout vada softwaru vedoucí ve výsledku $\mathrm{k}$ újmě způsobené autonomním systémem. V takovém případě může být obtížné určit, jaká konkrétní osoba danou vadu zavinila a měla by být odpovědná za výslednou škodu.

Z výše popsaných důvodů by odpovědnostní model měl rozlišovat, zda tvůrce příslušné komponenty měl $\mathrm{z}$ jejího použití $\mathrm{v}$ rámci daného autonomního systému komerční prospěch, resp. zda k danému použití došlo v návaznosti na jeho komerční aktivity, nebo nikoli. Pokud újmu způsobí komponenta šířená mimo komerční aktivity původce, pak by měla jeho odpovědnost být vyloučena mimo případy, kdy újma vznikne z jeho hrubé nedbalosti či úmyslně.

\subsection{PROCESNÍ OTÁZKY}

V neposlední řadě nelze pominout, že systém soukromoprávní odpovědnosti, ačkoli je hmotněprávním institutem, se prakticky realizuje v civilním, popř. trestním procesu, který může na uplatnění nároku klást větší či menší překážky. Odpovědnostní nárok, který je po hmotněprávní stránce jednoznačně opodstatněný, tak může být relativizován příliš vysokými procesními nároky na jeho uplatnění, např. nutností složitého dokazování. ${ }^{21}$

Ideální model odpovědnosti by tedy poškozeným měl umožňovat opodstatněné nároky uplatnit relativně snadno. Vědomí, že odpovědnostní systém takové uplatnění umožňuje, pak bude zpravidla vést odpovědné osoby k tomu, aby poškozené kompenzovaly samy, bez nutnosti soudního uplatnění nároku, vzhledem k nižším transakčním nákladům mimosoudního řešení. Současně by však tento model odpovědnosti neměl připouštět

${ }^{20}$ K podmínkám použití open source softwaru blíže srov. MYŠKA, M., TOMÍŠEK, J. Práva k datům a software. In: POLČÁK, R. a kol. Právo informačních technologií. Praha: Wolters Kluwer ČR, 2018. s. 195.

${ }^{21}$ Srov. HUBBARD, 2014, op. cit., s. 1828. 
př́liš snadné uplatnění nároků, aby neotevíral cestu neopodstatněným žalobám zatěžujícím odpovědné osoby. ${ }^{22}$

\section{ODPOVĚDNOST ZA AUTONOMNÍ SYSTÉM DE LEGE LATA}

\subsection{ODPOVĚDNOST ZA PROVOZNÍ ČINNOST}

De lege lata lze přepokládat, že na odpovědnost provozovatele za autonomní systém by byl aplikován $\S 2924$, popř. 2925 ObčZ, tedy odpovědnost za škodu z provozní činnosti, popř. za škodu provozem zvláště nebezpečným. Působnost odpovědnosti za škodu z provozní činnosti je relativně limitovaná díky svému omezení na škody z činnosti výdělečné. Pokud by autonomní systém byl použit jako zařízení k výdělečné činnosti (např. obsluha na zákaznické lince pojištovny), odpovídal by za škodu vzniklou z jeho provozu provozovatel dané činnosti bez ohledu na zavinění, ovšem pouze pokud by škoda měla podstatu v samotné činnosti ${ }^{23}$ (např. pokud by autonomní systém nezaznamenal nahlášenou pojistnou událost).

Vyloučení aplikace příslušného odpovědnostního institutu by bylo možné, pokud by bylo prokázáno, že škoda nevyplývá z povahy provozované výdělečné činnosti ${ }^{24}$ (například, že autonomní systém na zákaznické lince finanční instituce poskytl klientovi chybné informace o počasí, ač příslušná instituce takovou informační službu zjevně neposkytuje a autonomní systém pouze získal data požadovaná zákazníkem někde na internetu). Liberace provozovatele by pak byla možná, pokud by prokázal, že vynaložil veškerou možnou péči, kterou po něm lze rozumně požadovat, aby ke škodě nedošlo. Takový důkaz by byl možný např. $v$ případě, kdy by provozovatel systém náležitě vybral, patřičně jej vybavil pro výkon dané činnosti (typicky náležitým tréninkem nad relevantními daty) a podnikl přiměřená

${ }^{22}$ Srov. POLČÁK, 2018, op. cit., s. 553.

${ }^{23}$ Srov. VOJTEK, P. Náhrada újmy z provozních činností (vybrané otázky). Soudní rozhledy. [online]. 2015, č. 6, [cit. 14. 8. 2018] s. 202 a násl.

${ }^{24}$ Srov. rozsudek Nejvyššího soudu ze dne 25. 11. 2009, sp. zn. 25 Cdo 2429/2007 in VOJTEK, 2015, op. cit., s. 202 a násl. 
preventivní opatření (např. poučením zákazníků, že nekomunikují se živým operátorem apod.). ${ }^{25}$

Naproti tomu $\mathrm{v}$ př́padě škody způsobené provozem zvláště nebezpečným se výdělečný charakter př́slušné činnosti nevyžaduje. Postačí, že škoda vznikne $\mathrm{z}$ provozu, u kterého nelze předem rozumně vyloučit možnost vzniku závažné škody ani při vynaložení řádné péče. Je přitom otázkou, kdy může být autonomní systém považován za takový provoz. Dle judikatury provozem zvláště nebezpečným je rovněž „faktická existence zařízení vyvolávajícího vedlejší škodlivé účinky přírodní síly tímto zařízením využívané, jestliže tyto účinky nejsou v daných podmínkách plně ovladatelné a je s nimi spojen vysoký stupeň pravděpodobnosti vyvolání vážných škod v okolí.“26

S ohledem na výše analyzované charakteristiky autonomních systémů (zejména omezenou možnost jejich kontroly) bude znak neovladatelnosti ve většině př́padů jejich praktického nasazení naplněn. Zda je autonomní systém schopen vyvolávat vážné škody, a zda jsou tyto škody pravděpodobné i při vynaložení rozumné péče, ${ }^{27}$ pak bude záležet na konkrétním typu autonomního systému a jeho aplikaci. Např́klad u robotického vysavače nejspíše nebude jeho běžné použití znamenat vysoké nebezpečí vzniku škod. Pokud však půjde o výše zmiňovaný autonomní systém obsluhující klienty na zákaznické lince, zde díky jeho limitované „inteligenci“ zřejmě nepůjde i při náležité péči zcela vyloučit, že se systém dopustí v komunikaci s volajícím chyby a způsobí mu tím újmu. ${ }^{28}$

V takové situaci pak nastupuje povinnost nahradit škodu způsobenou zdrojem zvýšeného nebezpečí. Vhodným měřítkem zvýšeného nebezpečí je zde dle názoru autora porovnání se škodou, která by vznikla, pokud by na daném místě působil člověk, resp. systém obsluhovaný člověkem. Pokud by

${ }^{25}$ Tím však není vyloučena objektivní odpovědnost provozovatel ze smlouvy nebo dle zvláštních předpisů.

${ }^{26}$ Srov. rozsudek Vrchního soudu v Praze ze dne 31. 10. 1995, sp. zn. 6 Cdo 52/94 in VOJTEK, 2015, op. cit., s. 202 a násl.

${ }^{27}$ Srov. VOJTEK, 2015, op. cit., s. 202 a násl.

${ }^{28}$ Jak uvádí Vojtek, ačkoli ObčZ ve vztahu k provozní činností hovoří o škodě, je třeba dovozovat, že se odpovědnost vztahuje i na nemajetkovou újmu. Srov. VOJTEK, 2015, op. cit., s 202 a násl. 
v dané situaci způsobil újmu i provoz nezaložený na autonomním systému (např. při telefonické objednávce by ani lidský operátor nerozpoznal, že zákazník má na mysli jiné zboží a došlo by k chybné objednávce), pak by se odpovědnost za provoz zvláště nebezpečný neměla aplikovat. Pokud by však člověk nejspíše újmě v daném případě předešel (např. by rozpoznal, že zákazník nejspíš nechce tisíc kusů daného zboží, ale jen deset, a že chybná informace vznikla jen nízkou kvalitou telefonního hovoru), pak by již příslušný odpovědnostní institut měl být aplikovatelný. ${ }^{29}$ Autor se zde přitom přiklání $\mathrm{k}$ názoru Hubbarda, že s ohledem na jistou technologickou skepsi by se soudy spíše přikláněly ke kvalifikaci autonomního systému jako provozu a priori nebezpečného. ${ }^{30}$

Liberace z odpovědnosti za škodu vzniklou provozem zvláště nebezpečným je přitom možná pouze $\mathrm{v}$ případě, že příslušnou újmu způsobila vyšší moc nebo že ji způsobilo vlastní jednání poškozeného nebo neodvratitelné jednání třetí osoby, tedy například, že přiměřeně zabezpečený autonomní systém byl napaden a ovlivněn vnějším útočníkem způsobem naplňujícím znaky trestného činu.

\subsection{ODPOVĚDNOST ZA VĚC}

Krausová, Kolaříková i Mikeš v kontextu autonomních systémů zvažují také aplikovatelnost odpovědnosti za škodu, kterou věc způsobí sama od sebe dle § 2937 ObčZ. ${ }^{31}$ Tento institut se aplikuje, pokud škoda vznikne ze samotné podstaty věci a odpovědnost nese ten, kdo nad věcí měl mít dohled, popř. vlastník. Liberace je možná, pokud jinak odpovědná osoba prokáže, že náležitý dohled nad věcí nezanedbala. Krausová přitom spatřuje problém při aplikaci tohoto institutu v určení, kdy škoda vznikla z příčiny uvnitř autonomního systému a kdy $\mathrm{z}$ vnějšího podnětu (např. chybných dat), a dále v otázce určení míry povinného dohledu. ${ }^{32}$ Mikeš rovněž spatřuje problém ve standardu povinného dohledu, který může být

\footnotetext{
${ }^{29}$ Obdobně k odpovědnosti za vady výrobku srov. HUBBARD, 2014, op. cit., s. 1858.

${ }^{30}$ Srov. HUBBARD, 2014, op. cit., s. 1833.

31 Srov. KRAUSOVÁ, 2018, op. cit., KOLAŘíKOVÁ, 2018, op. cit., s. 14 a násl. MIKEŠ, 2018, Bulletin advokacie, op. cit., s. 20.

32 Srov. KRAUSOVÁ, 2018, op.cit.
} 
u autonomních systémů nedosažitelný a dále v potenciálně problematickém určení provozovatele, resp. vlastníka. ${ }^{33}$

Podmínkou aplikace tohoto institutu je však samotné podřazení autonomního systému pod pojem věci. To nebude problematické u autonomních systémů $\mathrm{s}$ hmotnou složkou, nicméně jak již bylo uvedeno $\mathrm{v}$ části 2 tohoto příspěvku, významnou část autonomních systémů budou v budoucnu tvořit systémy softwarové, přičemž software nelze bez dalšího dle ObčZ považovat za věc. ${ }^{34}$ Přitom zde není prostor ani pro analogickou aplikaci § 2937 na věci nehmotné, jelikož $\S 2895$ ObčZ připouští objektivní odpovědnost jen $\mathrm{v}$ případech stanovených zákonem.

Další problém lze shodně s Krausovou a Mikešem spatřovat ve stanovení požadované míry dohledu, resp. v tom, že u plně autonomních systémů není toto kritérium efektivně aplikovatelné. Pokročilý stupeň autonomie systému totiž spočívá právě $\mathrm{v}$ tom, že tyto systémy pro svůj běžný provoz nevyžadují dohled. ${ }^{35}$ Ve výsledku tedy tento institut může být aplikovatelný na omezený okruh případi̊ škody zpơsobené autonomním systémem $s$ hmotnou složkou, který zjevně není určen k použití bez dohledu, a kde bude možné prokázat, že škodu způsobil tento systém sám od sebe (bez vnější příčiny). Podle názoru autora však bude tento okruh případů oproti šíri aplikace odpovědnosti za škodu zpo̊sobenou provozní činností, resp. provozem zvláště nebezpečným, relativně úzký.

\subsection{ODPOVĚDNOST ZA VADY VÝROBKU}

Na původce autonomního systému by de lege lata byl nejspíše aplikován institut odpovědnosti za vady výrobku podle § 2939 ObčZ. Jeho limitem je již výše diskutovaný převážně softwarový charakter autonomních systémů, nebot institut odpovědnosti za vady výrobku dle ObčZ se aplikuje pouze na

\footnotetext{
Srov. MIKEŠ, Bulletin advokacie, 2018, op. cit., s. 20.

${ }^{34}$ K diskuzi kvalifikace nehmotných statků jako věcí a předmětů vlastnictví ve smyslu ObčZ srov. MYŠKA, M., TOMÍŠEK, J, 2018, op. cti. s. 119.

35 Srov. HUBBARD, 2014, op. cit., s. 1845.
} 
věci movité. Na software nelze aplikovat ani evropskou směrnici, ze které $\S 2939$ vychází. $^{36}$

Přesto bude existovat řada autonomních systémů, které znaky výrobku dle § 2939 splní. V takovém případě by odpovědnost nastoupila v případě škody vzniklé tím, že by daný systém nebyl tak bezpečný, jak to od něho lze rozumně očekávat, se zřetelem ke všem okolnostem a zejména ke způsobu, jakým je na trh uveden nebo nabízen, k předpokládanému účelu, jemuž má sloužit, jakož i s přihlédnutím $\mathrm{k}$ době, kdy byl uveden na trh. ${ }^{37}$ Okruh odpovědných osob je přitom široký a zahrnuje výrobce, společně a nerozdílně s ním dovozce, a toho, kdo výrobek označil svým jménem, ochrannou známkou nebo jiným způsobem. Dodavatel pak může být rovněž odpovědný, pokud poškozenému neposkytne informace o dodavateli či dovoz$\mathrm{ci}^{38}{ }^{38}$ a odpovědnost může krýt i výrobce součásti systému. ${ }^{39}$

Liberace je přitom možná na základě více okolností upravených v § 2942 ObčZ. Podmínky liberace jsou však formulovány relativně úzce a $\mathrm{z}$ odpovědnosti vylučují v prvé řadě nekomerční aktivity. $\mathrm{V}$ praxi by komerčně působící výrobce autonomního systému, nebo jeho součásti, musel prokázat, že si škodu způsobil poškozený sám ${ }^{40}$, škoda vznikla vadou objevivší se až po uvedení systému na trh ${ }^{41}$ nebo že mu stav vědeckých a technických znalostí v době, kdy uvedl systém na trh, neumožnil zjistit jeho vadu. ${ }^{42}$ Pokud by se mu nepodařilo prokázat žádnou z těchto skutečností, neměl by možnost se $\mathrm{z}$ odpovědnosti liberovat, přestože by vynaložil nejvyšší možné úsilí k tomu, aby jím vytvářený systém byl maximálně bezpečný, a přestože by neměl možnost škodě zabránit jinak než tím, že by daný systém vůbec neuvedl na trh.

${ }^{36}$ Srov. ALHEIT, K. The applicability of the EU Product Liability Directive to software [online]. Comparative and International Law Journal of Southern Africa, 2001, roč. 34, č. 2. s. 201. Alheit dochází $\mathrm{k}$ závěru, že se na software tato směrnice aplikuje, ovšem na základě nesprávného argumentu, že software se svým během v počítači stává hmotnou věcí.

37 Srov. § 2941 odst. 1 ObčZ.

${ }^{38}$ Srov. § 2940 ObčZ.

39 Srov. § 2942 odst. 3 ObčZ.

40 Srov. § 2942 odst. 1 ObčZ.

${ }^{41}$ Srov. § 2942 odst. 2 písm. b) ObčZ.

42 Srov. § 2942 odst. 2 písm. e) ObčZ. 


\section{ODPOVĚDNOST ZA AUTONOMNÍ SYSTÉM DE LEGE FERENDA}

Z výše předložené analýzy plyne, že stávající model odpovědnosti dle ObčZ do značné míry naplňuje požadavky na ideální model odpovědnosti za autonomní systém. Odpovědnost je primárně alokována na provozovatele autonomního systému podle pravidel odpovědnosti za provoz zvláště nebezpečný. Poškození tak budou mít vždy $\mathrm{k}$ dispozici subjekt, na kterém se mohou hojit ve vztahu k vzniklé újmě. Současně však odpovědnost provozovatele není absolutní a v odůvodněných případech je možná jeho liberace.

Sekundárně se pak poškozený může hojit na původci autonomního systému, pokud daný autonomní systém lze považovat za výrobek z hlediska pravidel odpovědnosti za vady výrobku. Této odpovědnosti se může dovolávat též provozovatel autonomního systému, který je sám poškozeným (např. pokud činností autonomního systému na zákaznické lince finanční instituce vznikne újma samotné finanční instituci), a ten provozovatel, který podle pravidel objektivní odpovědnosti nahradil škodu poškozenému, ačkoli ji způsobil původce systému. Automaticky je přitom z odpovědnosti vyloučena újma vzniklá z nekomerčních aktivit původce.

Diskutabilní však je, zda systém odpovědnosti za vady výrobku působí na původce autonomních systémů dostatečně preventivně a zde je správně nastaven procesní standard dokazování. Krausová a Mikeš poukazují na to, že právní režim odpovědnosti za vady výrobku umožňuje příliš širokou liberaci výrobce a může ponechat poškozené bez adekvátní kompenzace. ${ }^{43}$ V úvahu je však třeba vzít širokou odpovědnost provozovatele autonomního systému. Díky ní by situace, kdy poškozený nebude kompenzován, měla nastávat jen výjimečně a $\mathrm{v}$ odůvodněných případech, protože se poškozený bude moci běžně hojit na provozovateli autonomního systému, a to i v případě, kdy se výrobce tohoto systému ze své odpovědnosti liberuje. Problém potenciálně široké liberace tak zůstává relevantní pouze ve vztahu k případu, kdy je poškozený současně provozovatelem systému, a ve vztahu

43 Srov. Krausová, 2017, op. cit. a Mikeš, 2018, Právní rozhledy, op. cit. 
k regresu provozovatele, který kompenzoval poškozeného, vůči výrobci systému.

Dle názoru autora je však tento problém ryze potenciální a právní režim odpovědnosti za vady výrobku je naopak pro výrobce př́liš přísný. Důvodem je nastupující povinnost krýt škody, kterým nemůže výrobce zabránit ani s náležitou péčí a úsilím. Do značné míry nepředvídatelný charakter chování autonomního systému je totiž jeho inherentním, a naopak žádoucím znakem. ${ }^{44}$ Lze tak dovozovat, že každý výrobce autonomního systému si musí být $s$ ohledem na stav techniky vědom, že systém může působit škody, a tím je vyloučeno, aby se $\mathrm{z}$ odpovědnosti za vadu autonomního systému jako výrobku liberoval tím, že vadu nemohl zjistit s ohledem na stav vědeckých a technických znalostí v době, kdy uvedl výrobek na trh.

Pokud by tedy nebyl výrobce $\mathrm{v}$ konkrétním př́ípadě schopen prokázat zavinění poškozeného, ani prokázat, že se systém „naučil“ závadnému chování na určitých datech až po uvedení na trh, pak by nesl za př́slušnou škodu odpovědnost, bez ohledu na rozsah jím vynaložených investic do preventivních opatření. Takové nastavení odpovědnosti by mohlo celkově demotivovat výrobce autonomních systémů od uvádění př́slušných systémů na trh, ale současně také od investic do preventivních opatření, a to $\mathrm{z}$ důvodu vědomí, že odpovědnost za škodu ponesou bez ohledu na to, kolik do prevence investují.

Naopak v prípadech, kdy původce autonomního systému bude zcela vyňat $\mathrm{z}$ odpovědnosti za jeho vady jako vady výrobku (primárně proto, že by šlo o ryze softwarový systém), může vznikat situace nespravedlivá pro poškozené, resp. provozovatele systémů, protože zde odpovědnost bude ponechána běžnému modelu subjektivní odpovědnosti s důkazním břemenem na poškozeném, popř. provozovateli regresně uplatňujícím odpovědnostní nárok. Poškozený i provozovatel budou přitom zpravidla mít značný problém prokázat zavinění na straně výrobce s prríčinnou souvislostí ke vzniklé škodě, a to s ohledem na složitou či zcela nemožnou analýzu příčin chování autonomního systému. Výrobce současně nebude dostatečně motivován k provádění preventivních opatření, bránících vzniku škod.

\footnotetext{
${ }^{44}$ Srov. SCHERER, 2016, op. cit., s. 366.
} 
Z těchto důvodů dle názoru autora současná úprava odpovědnosti za vady výrobku nenaplňuje požadavky na přiměřenou alokaci odpovědnosti za autonomní systém. Na původce autonomních systémů nepůsobí dostatečně preventivně, když je na jednu stranu činí de facto absolutně odpovědnými u systémů $s$ hmotnou složkou a na druhou stranu nedostatečně odpovědnými u softwarových systémů. $\mathrm{V}$ případě softwarových systémů není rovněž zajištěna dostatečná kompenzace provozovatelů autonomních systémů, příp. samotných poškozených, protože by u nich pro založení odpovědnosti tvůrce softwaru bylo nutné prokázat jeho zavinění.

Pravidla odpovědnosti za vady výrobku by se proto měla ve vztahu k autonomním systémům změnit ve dvou směrech. Prvním je rozšiřrení liberačních důvodů výrobce, resp. dovozce autonomního systému, pokud prokáže, že $\mathrm{k}$ předejití škodě vynaložil veškerá rozumná opatření. Tento standard by umožnil právně akceptovat skutečnost, že autonomní systém může $s$ vědomím výrobce jednat nepředvídaně a působit škody, a současně by motivoval výrobce autonomních systémů $\mathrm{k}$ jejich adekvátnímu zabezpečení.

Druhým směrem je pak rozšíření takto konstruované odpovědnosti za vady i na softwarové autonomní systémy. Toto nastavení by jednak působilo preventivně na tvůrce takovýchto softwarových systémů a současně umožňovalo poškozeným, resp. provozovatelům $\mathrm{v}$ případě vzniku škody způsobené takovým systémem, získat kompenzaci, pokud škodě mohl rozumně předejít původce. Zachována by zde přitom měla být liberace nekomerčních aktivit, jež by chránila tvůrce open source software.

Systém stojící primárně na odpovědnosti provozovatele autonomního systému by pak měl být doplněn povinným pojištěním odpovědnosti tohoto provozovatele. Bez tohoto prvku by v praxi nejspíše nastávala řada př́padů, kdy by poškození nebyli spravedlivě kompenzováni pro nedostatek prostředků na straně provozovatele (a současně omezení odpovědnosti výrobce), nebot újma způsobená výše diskutovanými autonomními systémy může být značná, vč. např. újmy na zdraví a ztrát na životech.

Paralelně se systémem pojištění by pak logicky měl vzniknout garanční fond pro krytí nepojištěných škod, které však spadnou do rozsahu př́slušné 
objektivní odpovědnosti provozovatele. Prevence nepřiměřeného objemu výplat z garančního systému s sebou však nese nutnost monitorovat, zda jsou relevantní systémy adekvátně pojištěny, a zavést sankce pro případ, že systém řádně pojištěn nebude. Nutnou podmínkou tohoto monitorování však není registrace všech autonomních systému u instituce, která by proaktivně a plošně monitorovala, zda jsou pojištěny. Naopak zde může být pro začátek dostatečná namátková kontrola v relevantních oblastech, kde mohou autonomní systémy působit, a teprve $\mathrm{v}$ případě konkrétních negativních zkušeností by měla být zavedena robustnější opatření. Povinnost registrovat autonomní systémy by totiž mohla znamenat nepřiměřenou zátěž pro provozovatele a opět vytvářet bariéru pro jejich uvádění do provo$\mathrm{zu}$.

Významným praktickým problémem by pak nepochybně bylo stanovení výše pojistného. ${ }^{45} \mathrm{~V}$ případech, kde se běžně pracuje s povinným pojištěním, jako je provoz motorových vozidel, je určení výše pojistného rizika, a od něj se odvíjející výše pojistného, relativně typizovanou úlohou. V případě autonomních systémů by musely být minimálně zpočátku tyto parametry stanovovány na individuální bázi pro každé jednotlivé nasazení autonomního systému. Na druhou stranu tento přístup otevírá cestu ke zohlednění okolností konkrétního zpơsobu použití autonomního systému, které se mohou pro jeden typ systému významně lišit, a výrobce by je nebyl schopen při sjednávání pojištění na své straně efektivně reflektovat.

Jak přitom správně podotýká Polčák, problematika odpovědnosti za autonomní systémy není specifická pro Českou republiku a s ohledem na předpokládanou distribuci těchto systémů napříc vnitřním trhem Evropské unie by zde bylo na místě upravit tuto problematiku sekundárním právem Evropské unie. Polčák v tomto směru navrhuje úpravu obdobnou omezení odpovědnosti poskytovateli̊ služeb informační společnosti, a to ve vztahu $\mathrm{k}$ výrobcům autonomních systémů, doplněnou garančním fondem pro krytí škod, pro něž nebude odpovědných osob. Taková úprava by přitom dle něj byla možná formou přímo účinného předpisu, tj. nařízení. Tento návrh zdů-

45 Srov. SCHERER, 2016, op. cit., s. 1812 a násl. 
vodňuje mj. tím, že není realistické do heterogenních právních řádů členských států zavádět nové, konstruktivní prvky odpovědnosti. ${ }^{46}$

Jak plyne z výše předložené diskuze, autor se ztotožňuje s potřebou dílčího omezení odpovědnosti vývojářů autonomních systémů. Takový model však nebude funkční bez harmonizované objektivní odpovědnosti jejich provozovatelů. Samotné krytí škod garančním fondem s příspěvky výrobců by dle názoru autora nepůsobilo motivačně na provozovatele, aby vybírali pro praktické nasazení bezpečné systémy. V modelu objektivní odpovědnosti provozovatele, doplněném o povinné pojištění, by tuto motivaci vytvářela předpokládaná spoluúčast pojištěného na pojistném plnění. Současně by se príliš široká odpovědnost výrobců mohla negativně promítnout do pořizovacích cen autonomních systémů, nebot výrobci (a jejich pojistitelé) by mohli jen obtížně předvídat způsoby použití systémů (a tedy celkový objem možné újmy) a přispívat by museli za všechny systémy uváděné na trh, bez ohledu na jejich reálné uvedení do provozu.

$\mathrm{Z}$ toho důvodu považuje autor konstruktivní prvky odpovědnosti za autonomní systémy, obdobné naší domácí odpovědnosti za škodu z provozní činnosti nebo provozu zvláště nebezpečného, za nezbytné. Jejich zavedení formou nařízení by přitom nebylo možné s ohledem na hrozící terminologickou nejednotnost a neprovázanost ve vztahu k obecné úpravě odpovědnosti, která se mezi členskými státy Evropské unie značně odlišuje. $\mathrm{Z}$ toho důvodu by bylo vhodnější harmonizovat tuto oblast směrnicí, která by také současně modifikovala stávající úpravu odpovědnosti za vady výrobku a upravila i problematiku povinného pojištění provozovatelů. ${ }^{47} \mathrm{Je}$ však třeba podotknout, že oproti řešení, které předkládá Polčák, tento návrh řeší pouze otázku odpovědnosti soukromoprávní, nikoli správní či trestní.

46 Srov. POLČÁK, 2018, op. cit., s. 546.

47 Ve vztahu k povinném pojištění obdobně jako Směrnice Evropského parlamentu a Rady 2009/103/ES o pojištění občanskoprávní odpovědnosti z provozu motorových vozidel a kontrole povinnosti uzavřít pro případ takové odpovědnosti pojištění. In: EUR-Lex [online]. 


\section{ZÁVĚR}

S autonomními systémy je, s ohledem na jejich závislost na datových vstupech mimo kontrolu provozovatele a s ohledem na technologie strojového učení, spojeno riziko nemožnosti určit příčinu jimi zpo̊sobené škody a zprostředkovaně nemožnosti určit, kdo škodu zavinil. Pro spravedlivou kompenzaci osob, jimž autonomní systém způsobí újmu, je třeba odpovědnost za takovou újmu modelovat jako objektivní. Těžiště této odpovědnosti by mělo ležet na provozovateli autonomního systému, který má nejlepší znalost o konkrétním způsobu použití autonomního systému. Tyto požadavky naplňuje stávající úprava odpovědnosti za provoz zvláště nebezpečný dle ObčZ, která je na autonomní systémy aplikovatelná, v českém právu tedy není pro autonomní systémy nutné zakotvovat zcela nový odpovědností režim.

Sekundární odpovědnost by měla ležet na původci autonomního systému, ta by však neměla být absolutní, aby působila motivačně směrem $\mathrm{k}$ provádění preventivních opatření. Těmto požadavkům se blíží úprava odpovědnosti za vady výrobku dle ObčZ. Stávající úpravu by však bylo ve vztahu k autonomním systémům vhodné omezit umožněním liberace $\mathrm{v}$ případě, kdy výrobce prokáže, že k prevenci škody vynaložil maximální úsilí, a naopak rozšírit její působnost i na ryze softwarové autonomní systémy. Tyto modifikace jsou dle názoru autora schopny zajistit přiměřenou motivaci na straně původce systému k zavádění efektivních preventivních opatření, aniž by riziko odpovědnosti současně odrazovalo od vývoje apriori nebezpečných, ale společensky přínosných systémů. Poškozený by přitom neztratil možnost spravedlivé kompenzace díky objektivní odpovědnosti provozovatele.

Systém objektivní odpovědnosti by pak bylo vhodné doplnit systémem povinného pojištění a krytí nepojištěných škod, obdobně jako u motorových vozidel. Překážkou může být stanovení výše pojistného, které nebude ze začátku možné typizovat a bude třeba jej určovat jednotlivě pro každý případ.

Takový systém odpovědnosti, resp. jejího omezení a povinného pojištění by bylo vhodné na evropské úrovni zavést formou směrnice, jelikož úprava 
nařízením by zde byla jen stěží funkční s ohledem na terminologická i jiná specifika národních právních úprav civilní odpovědnosti a také s ohledem na již stávající úpravu odpovědnosti za vady výrobku evropskou směrnicí.

\section{SEZNAM LITERATURY}

\subsection{PRÁVNÍ PŘEDPISY A JUDIKATURA}

[1] Rozsudek Nejvyššího soudu ze dne 25. 11. 2009, sp. zn. 25 Cdo 2429/2007.

[2] Rozsudek Vrchního soudu v Praze ze dne 31. 10. 1995, sp. zn. 6 Cdo 52/94.

[3] Směrnice Evropského parlamentu a Rady 2009/103/ES o pojištění občanskoprávní odpovědnosti z provozu motorových vozidel a kontrole povinnosti uzavřít pro případ takové odpovědnosti pojištění.

[4] Zákon č. 89/2012 Sb., občanský zákoník, ve znění pozdějších předpisů.

\subsection{MONOGRAFIE A ČASOPISECKÉ ČLÁNKY}

[5] ALHEIT, K. The applicability of the EU product liability directive to software. Comparative and International Law Journal of Southern Africa [online]. 2001, roč. 34, č. 2, s. 188-209 [cit. 14. 8. 2018]. ISSN 0010-4051. Dostupné z: https://journals.co.za/content/cilsa/34/2/AJA00104051_212

[6] ALPAYDIN, E. Introduction to machine learning.Cambridge, Massachusetts: The MIT Press. 3. vydání, 2014, 605 s. ISBN 9780262028189.

[7] EVTIMOV, Ivan, a kol. Robust Physical-World Attacks on Deep Learning Models. arXiv.org [online]. Upraveno 10. 4. 2018 [cit. 14. 8. 2018]. Dostupné z: https://arxiv.org/abs/1707.08945

[8] HUBBARD, F. Patrick. "Sophisticated Robots": Balancing Liability, Regulation, and Innovation. Florida Law Review [online]. 2014, roč. 66, č. 5, s. 1803-1872 [cit. 14.8. 2018].Dostupné z: https://scholarship.law.ufl.edu/cgi/viewcontent.cgi?referer =https://scholar.google.cz/scholar?hl $=$ cs\&as_sdt $=0 \% 2 \mathrm{C} 5 \& \mathrm{q}=$ sophisticated + robots\&btnG $=$ \&httpsredir $=$ 1\&article $=1204 \&$ context $=$ flr

[9] KOLAŘÍKOVÁ, L. Odpovědnost (za) robota aneb právo umělé inteligence. In: Bulletin advokacie [online]. 2018, č. 3. s. 11-19. [cit. 14. 8. 2018]. Dostupné z: http://www.bulletinadvokacie.cz/odpovednost-za-robota-aneb-pravo-umele-inteligence? browser $=$ full

[10] KRAUSOVÁ, A. Status elektronické osoby v evropském právu v kontextu českého práva. Právní rozhledy [online]. 2017, č. 20, s. 700 a násl. [cit. 14. 8. 2018] Dostupné v beck-online.cz: $\quad$ https://www.beck-online.cz/bo/document-view.seam?documentId $=$ nrptembrg5pxa4s7giyf6427g4yda\&groupIndex $=0$ \&rowIndex $=0$

[11] MIKEŠ, S. Právo ve věku inteligentních strojů. Bulletin advokacie. 2018, č. 4. s. 17-22. ISSN 1210-6348 
[12] MIKEŠ, S. Vybrané otázky odpovědnosti za škodu způsobenou autonomním vozidlem. Právní rozhledy [online]. 2018, č. 13-14. s. 471. [cit. 14. 8. 2018] Dostupné v beck-online.cz: https://www.beck-online.cz/bo/chapterview-document.seam?documentId = nrptembrhbpxa4s7gezv6mjul5zv6nbxge\&groupIndex $=0$ \&rowIndex $=0$

[13] MYŠKA, M., TOMíŠEK, J. Práva k datům a software. In: POLČÁK, R. a kol. Právo informačních technologií. Praha: Wolters Kluwer ČR, 2018. s. 118-157. ISBN 978-80-7598-045-8.

[14] POLČÁK, R. Odpovědnost umělé inteligence a informační útvary bez právní osobnosti. In: V. ZOUFALÝ. XXVI. Karlovarské právnické dny. Praha: Leges, 2018. ISBN 978-80-7502-2899, s. 535-554

[15] SCHERER, M. U. Regulating artificial intelligence systems: Risks, challenges, competencies, and strategies. Harvard Journal of Law \& Technology [online]. 2016, roč. 26, č. 2 [cit. 14. 8. 2018]. Dostupné z: http://euro.ecom.cmu.edu/program/law/08-732/AI/Scherer.pdf

[16] Váchal, A. Česko dohání Německo a Kalifornii v autonomním řízení. Do sněmovny mírí novela, která povolí samořiditelná auta. IHNED.cz [online]. 14. 6. 2018 [cit. 14. 8. 2018]. Dostupné z: https://archiv.ihned.cz/c1-66168060-cesko-dohani-nemecko-a-kalifornii-v-autonomnim-rizeni-do-snemovny-miri-novela-ktera-povoli-samoriditelna-auta

[17] VOJTEK, P. Náhrada újmy z provozních činností (vybrané otázky). Soudní rozhledy [online]. 2015, č. 6, s. 202 a násl. [cit. 14. 8. 2018]. Dostupné v beck-online.cz: https://www.beck-online.cz/bo/document-view.seamdocumentId = nrptembrgvpxg4s7gzpxgxzsgaza\&groupIndex $=0$ \&rowIndex $=0$

\subsection{OSTATNÍ}

[18] Usnesení Evropského parlamentu ze dne 16. února 2017 obsahující doporučení Komisi o občanskoprávních pravidlech pro robotiku (2015/2103(INL)) Evropský parlament [online]. [cit. 14. 8. 2018]. Europarl.europa.eu Dostupné z: http://www.europarl.europa.eu/sides/getDoc.do?pubRef $=-/ /$ EP $/ /$ TEXT + TA + P8-TA-2017-0051 + 0 + DOC + XML + V0//CS

Toto dílo lze užít v souladu s licenčními podmínkami Creative Commons BY-SA 4.0 International (http://creativecommons.org/licenses/by-sa/4.0/legalcode). 